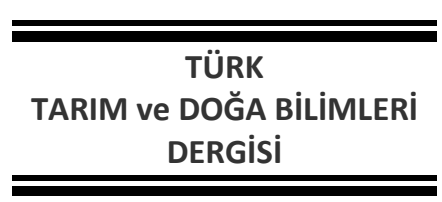

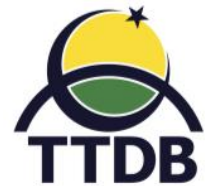

www.dergipark.gov.tr/turkjans

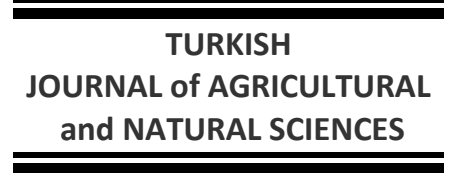

Research Article

Biology and Laboratory Rearing of Codling Moth, Cydia pomonella (L.) (Lepidoptera: Tortricidae) on Its Natural Host "Green Immature Apple" Malus domestica (Borkh) (Rosales: Rosaceae) $)^{¥}$

\author{
Akın KUYULU ${ }^{1}$, Hanife GENÇ2* \\ ${ }^{1}$ Çanakkale Onsekiz Mart University, Graduate School of Natural and Applied Science, Çanakkale, Turkey \\ ${ }^{2}$ Çanakkale Onsekiz Mart University, Faculty of Agriculture, Department of Agricultural Biotechnology, \\ Çanakkale, Turkey
}

*Corresponding author: hgenc@comu.edu.tr

Received: 20.05.2019

Received in Revised: 18.06.2019

Accepted: 04.07.2019

\begin{abstract}
The codling moth, Cydia pomonella Linnaeus, 1758 (Lepidoptera: Tortricidae) is an economically important pest of apple trees in Turkey and also in worldwide. The aim of this study was to report a continuous rearing method on green immature apples (Malus domestica cv. 'Gala') for C. pomonella and fundamental information of its biology. The experiments were conducted from 2017 to 2019 under the laboratory conditions. Eggs were laid individually or disorderly in small masses on the oviposition substrate in the adult cages. Adult food had a positive effect on the number of eggs laid per female and egg viability. Larvae developed through five instars based on head capsule measurements. Larval development was completed in $15.89 \pm 0.25$ days. Survival rate of larvae ranged from $24.1 \%$ and $92.6 \%$ based on larval density per apple. The duration of pupal development was $8.90 \pm 0.10$ days with $87.5 \%$ adult emergence. The life cycle was completed on average in $29.5 \pm 0.3$ days. Adult longevity was $12.2 \pm 0.60$ days for females and $16.7 \pm 1.90$ days for males. A single female laid about 12.3 eggs/day and a total of $85-200$ eggs with $83.9 \%$ viability. The codling moth has been reared continuously in the laboratory for two years with no evidence of disease in the colony.
\end{abstract}

Key words: Biology, Cydia pomonella, green immature apple, laboratory rearing, larvae competition.

\title{
Doğal Konukçusu "Yeşil Olgunlaşmamış Elma” Malus domestica (Borkh) (Rosales: Rosaceae) Üzerinde Elma İçkurdu, Cydia pomonella (L.) (Lepidoptera: Tortricidae)'nın Biyolojisi ve Laboratuvarda Yetiştirilmesi
}

\begin{abstract}
Özet
Elma içkurdu, Cydia pomonella Linnaeus, 1758 (Lepidoptera: Tortricidae), Türkiye'de elma ağaçlarında ekonomik olarak önemli zararlılarından biridir. Bu çalışmanın amacı C. pomonella için yeşil olgunlaşmamış elma (Malus domestica cv. 'Gala') üzerinde yetiştirme metodunun ve temel biyolojik özelliklerinin rapor edilmesidir. Deneyler laboratuvar koşullarında 2017'den 2019 yılına kadar yürütülmüştür. Yumurtalar, ergin kafesleri içerisindeki ovipozisyon substratı üzerine doğduran veya dağınık küçük kümeler halinde bırakılmıştır. Ergin besini dişi başına yumurta bırakılan yumurta sayısı ve canlılığı üzerinde olumlu etki göstermiştir. Larvalar baş kapsül ölçümlerine göre beş dönem yoluyla geliştiler. Larva dönemi yaklaşık $15.89 \pm 0.25$ günde tamamlanmıştır. Larva döneminde canlı kalma oranı, elma başına larva yoğunluğuna bağlı olarak \%24.1 ve \%92.6 arasında değişmiştir. Pupa gelişme süresi, \%87.5 ergin çıkış oranı ile ortalama $8.90 \pm 0.10$ gün sürmüştür. Yaşam döngüsü yaklaşık $29.5 \pm 0.3$ günde tamamlanmıştır. Ergin ömür uzunluğu, dişilerde $12.2 \pm 0.60$ gün, erkeklerde $16.7 \pm 1.90$ gündür. Çiftleşmeden sonra tek bir dişi, yaşamı boyunca yaklaşık 12.3 yumurta/gün ile \%83.9 canlılıkta toplamda 85-200 yumurta bırakmıştır. Elma içkurdu, laboratuvarda kolonisinde hiçbir hastalık belirtisi gözlenmeden 2 yıl boyunca sürekli yetiştirilmiştir.
\end{abstract}

Anahtar kelimeler: Biyoloji, Cydia pomonella, yeşil olgunlaşmamış elma, laboratuvar yetiştirmesi, larva rekabeti. 


\section{Introduction}

Apple, Malus domestica Borkh (Rosaceae), is an economically important crop, and is cultivated worldwide. It is distributed to in a wide range of ecology extending from the much warmer environs of Colombia, S.A., and Indonesia to the extreme cold of Siberia and North China (Hancock et al., 2008). According to FAOSTAT data (FAOSTAT, 2017), leading countries of apple cultivation are China, U.S.A, Turkey, Poland, India, Iran and Italy with production of over 2 million tons of apple. Turkey is the third largest apple producing country in the world (3.032.164 tones) in 2017. Apple trees and apple fruits are infested by several insects, including moths, mites, leafrollers, leafminers, jewel beetles and bark beetles (Blommers, 1994). The codling moth, Cydia pomonella (L.) (Lepidoptera: Tortricidae) is serious pest of apple fruits. Larvae feed on the fruit directly, creating spiral galleries towards the seed chamber of fruit and severely effects quality of fruit by feeding in the mesocarp of the apple and in the kernel (Beers et al., 2003; Öztemiz et al., 2017). Without any plant protection measures, damage may reach $60-95 \%$ of apple production (Kuyulu and Genç, 2018). Additionally, codling moth larvae feed on several plant species belonging to various families, including as peaches (Prunus persica L.), pears (Pyrus sp.), nectarines (Prunus sp.), plums (Prunus sp.) quinces (Cydonia oblonga Mill), walnut (Junglas regia L.), sweet cherry (Prunus avium L.) and wild haws (Crataegus sp.) (Barnes, 1991).

The codling moth originated in SouthEastern Europe (Boivin et al., 2004) and is now mainly distributed in Europe and Asia as well as in North America (Jiang et al., 2018). Although adult flight capacity is limited, the codling moth has become a worldwide pest because of the variety of hosts, the spreading of pome fruit culture, and increase of international trade and transportation (Thaler et al., 2008).

Since it has been known as important pest, several studies have been conducted related to its distribution (Jiang et al., 2018), genetic structure (Meraner et al., 2008; Men et al., 2013), insecticide resistance (İş̧̧i and Ay, 2017; Bosch et al., 2018), biological control (Öztemiz et al., 2017; Sigsgaard et al., 2017), mating disruption (Kovanci, 2015; McGhee et al., 2016), and field studies (Pajač et al., 2012; Blomefield and Gliomee, 2012).

A few studies have been conducted for rearing codling moth in the laboratory. Dickson et al (1952) developed a method for continuous rearing of codling moth on thinning apple by determining the importance of photoperiod in diapause. Geier and Briese (1978) revealed information about several aspects of laboratory breeding, such as infestation, handling procedures and design of mating cages, etc. Rearing methods encouraged several studies attempting to rear the pest on formulated diet for large-scale or mass rearing. Additionally, previous studies revealed the several aspects of codling moth, such as, biology, behavior, developing artificial diet and mass rearing method (Brinton et al., 1969; Howell, 1970; Hathaway et al., 1973).

Insect growth and reproduction depend on host plant availability and quality in terms of their phytochemicals (Nation, 2015). Laboratory rearing of an insect include evaluation of host plant efficiency for rearing, the biological parameters of its life cycle, survival rate of biological stages, body weight, developmental time, fecundity, fertility, oviposition period, sex ratio and adult longevity (Awmack and Leather, 2002). Biological information from rearing the codling moth on its natural host in the laboratory may contribute to use of integrated pest management (IPM) strategies.

The aim of this study is to report a continuous rearing method on green immature apples in the laboratory. It was also aimed to determine fundamental biological parameters such as the developmental period of immature stages, effects of larval density per apple, and the efficiency of adult food on fitness parameters.

\section{Materials and Methods \\ Colony maintenance and laboratory rearing}

Infested apple fruits with codling moth was obtained from apple orchards (Malus domestica) in the vicinity of Ayvacık in Çanakkale, Turkey in 2017, and brought to laboratory for colony maintenance. They were placed into plastic containers $(30 \times 18 \times 8$ $\mathrm{cm}$ ) with a chiffon lid for larval development. When larvae become mature, corrugated cardboard strips were provided as pupation side. The pupae were gently harvested with soft forceps, and transferred to screen cages $(20 \times 20 \times 20 \mathrm{~cm})$. Emerged adults were used to maintain a laboratory colony, at $25 \pm$ 1 으, $60 \% \mathrm{RH}$, and 16:8 h (light: dark) photoperiod. Codling moths were reared on green immature apples by modifying the procedures in previous studies (Dickson et al., 1952; Geier and Briese, 1978; Vetter et al., 1989).

\section{Egg production}

Codling moth females lay eggs on almost any smooth surface, and prefer to oviposit during natural twilight (Dickson et al., 1952). The inner surfaces of cages were covered with rough screen and wax paper strips $(20 \times 20 \mathrm{~cm})$ were placed inside cages to stimulate egg laying (Fig. 1a). Strip with 
eggs were removed daily and replaced with new ones. Eggs were washed with $0.3 \%$ propionic acid solution, rinsed, air dried and incubated at $25 \pm 1$ 으
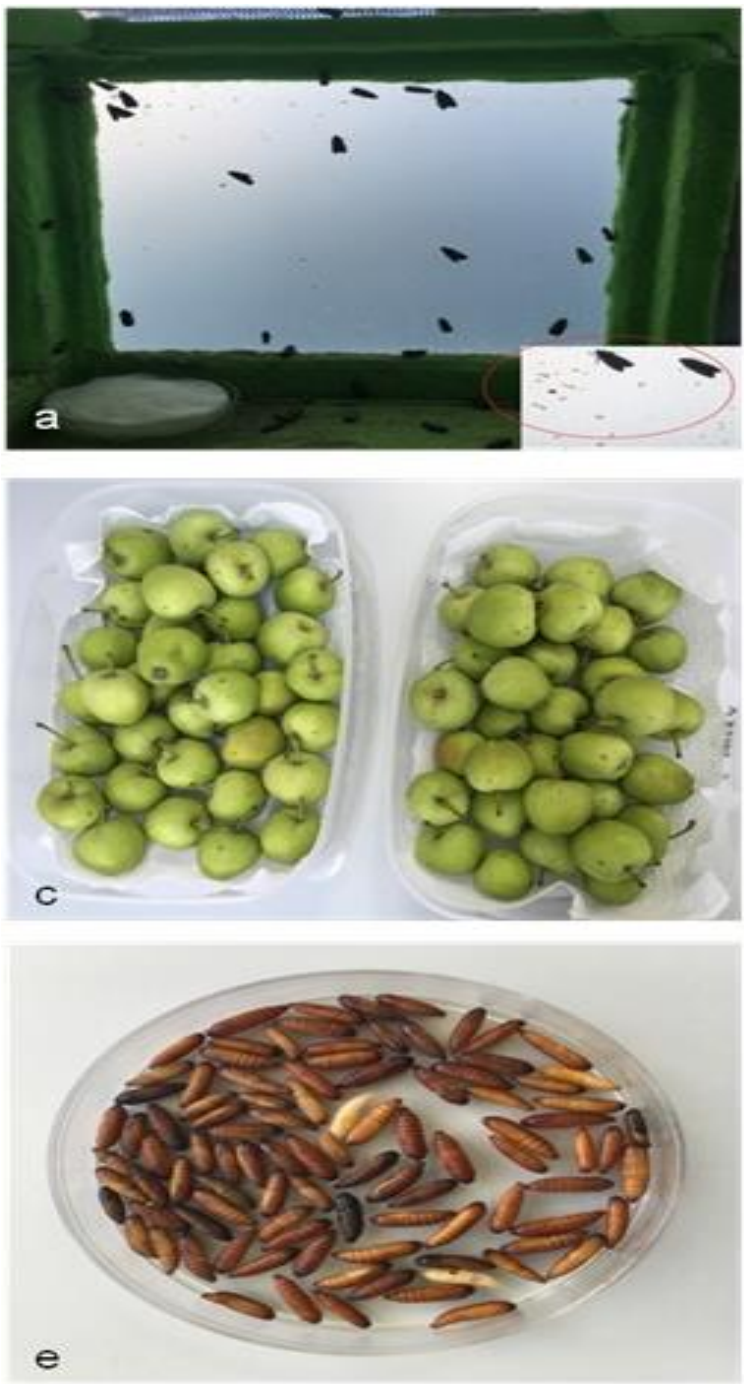

in a plastic cup covered with a lid until hatching (Fig. 1b).
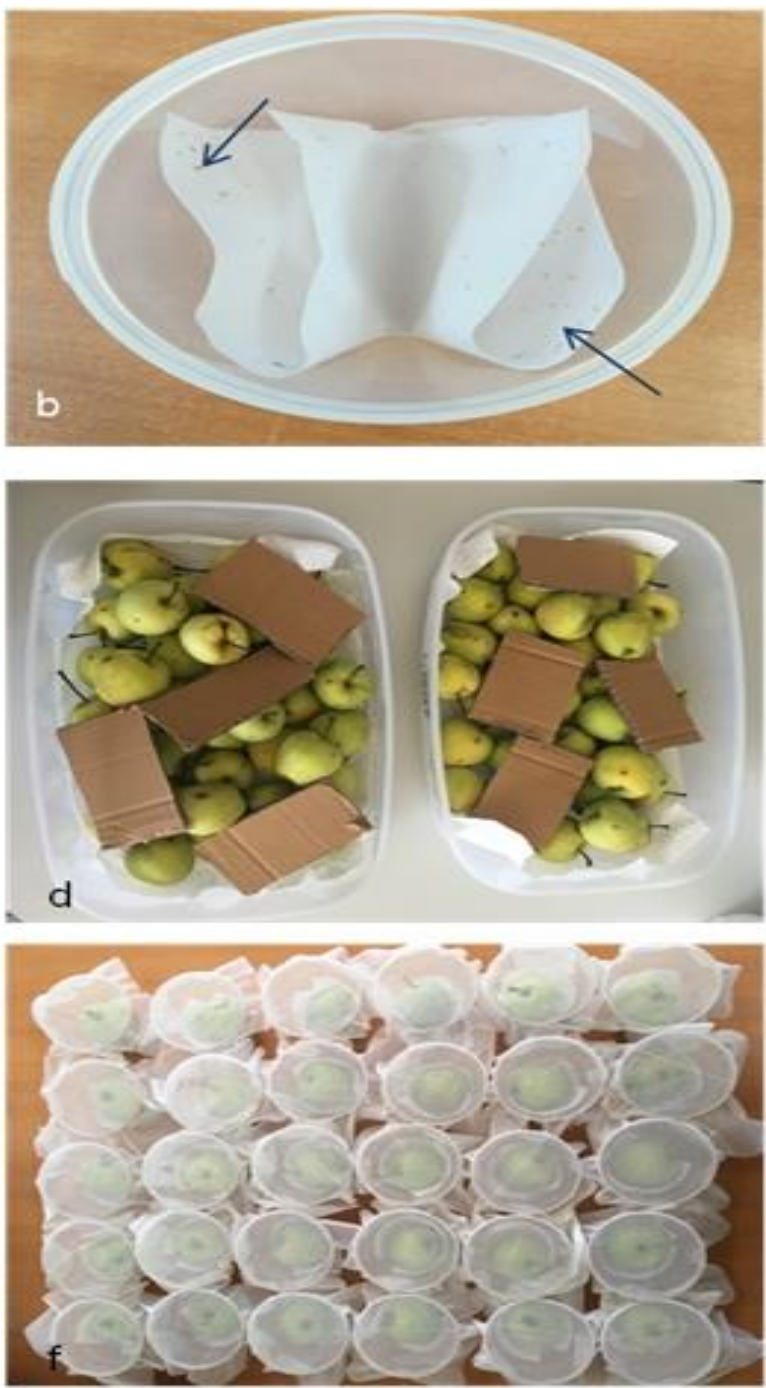

Figure 1. Laboratory rearing procedure and maintenance of the codling moth, Cydia pomonella. (a) Inside the adult cage, (b) Egg incubation, (c) Manually infested apple for larvae, (d) Strips of corrugated cardboard in the larva rearing container, (e) Pupae harvested from cocoon, (f) Rearing of individual larvae.

\section{Rearing larvae and adults}

First instar larvae were manually transferred to green immature apples to determine larval density with cohorts of similar age. Green immature apples (20-25 g) were perforated a few mm deep by sterile needles and then 1-3 instars were transferred by a camel hairbrush. Laboratory rearing was conducted using 100-150 apple infested with 1-3 instars. The infested apples were held in plastic containers $(30 \times 18 \times 8 \mathrm{~cm})$ with a piece of paper towel at the bottom which helped absorb excessive moisture coming from the infested apple during larval feeding (Fig. 1c). The strips of corrugated cardboard, into which the larvae crawl to pupate, were set on top of the apples in larval rearing containers (Fig. 1d). After 15-20 days, the strips of corrugated cardboard were removed from rearing containers, and pupae were gently harvested by soft forceps, placed in a petri dish (Fig. $1 \mathrm{e})$, and transferred to rearing cages. Each adult rearing cage had about 100-150 moths in the laboratory. As an adult food, $10 \%$ sugar solution soaked on cotton balls in a petri dish was provided.

\section{Storage of apples}

Small (3-4 cm diameter), green immature apples, 'Gala' variety grafted onto M9 rootstocks were obtained from the vicinity of Ayvacık in Çanakkale. The green immature apples were selected for laboratory studies because penetration by larva was easier and the apples last easily several weeks at room temperatures (Howell, 1991). The 
apples were washed in water to remove any insecticide residues on surface, surface-sterilized by dipping in $0.5 \%$ sodium hypochloride solution $(\mathrm{NaOCl})$ for 5-10 $\mathrm{min}$, then rinsed in water for 5-10 min, air dried and kept at +4 으 until used.

\section{Determination of biology and life history}

The oviposition wax paper strip was exposed to adult moths in oviposition cages for $24 \mathrm{~h}$. Subsequently, 130 freshly laid eggs on a strip were individually marked, and placed in transparent plastic cup. Eggs were monitored daily until hatching. The egg development time and egg viability were recorded. To determine the larval stages, a total of 30 apples were manually infested with a neonate larva with into a hole made by a sterile needle. Infested apples were placed individually in a plastic cup having a paper towel at the bottom and covered tightly with white chiffon fabric (Fig. 1f). The larvae were extracted from apples daily to make a measurement on the larva then the larva was reintroduced into a fresh apple. The number of instars was determined based on head measurements and molting $(n=30)$. The head capsule measurements were determined at the widest point by a micrometer in the ocular of stereo zoom microscope. Newly developed pupae from the laboratory colony were sexed (Genç, 2016), weighed, and individually placed in a plastic cup $(n=50)$. Survivorship, larval duration and sex ratio were recorded. To determine adult fitness parameters, the newly emerged male and female moths were placed in transparent cylindrical containers $(300 \mathrm{ml})$ for egging covered with chiffon lids $(n=20)$. Two adult food sources, $10 \%$ sugar solution and distilled water were tested. After mating, egging cups were examined daily for egg laying and adult mortality. When the female moth laid eggs on the cup's inner surface, each pair of moths were transferred into a new egging cup and then all eggs were recorded and kept until hatching. Number of eggs laid/female, egg fertility, adult longevity and preoviposition, oviposition and postoviposition times were recorded daily. All biological stages were observed and photographed by a stereo zoom microscope.

\section{Effects of larval competition}

To determine the effects of larval competition and developmental rate in an apple, 9 apples were individually weighed and manually infested with one larva/apple as the control, then 3, 4, 6 and 9 larvae per apple were used. A strip of corrugated cardboard $(4 \times 4 \mathrm{~cm})$ was placed in each cup to provide larvae crawl surface and pupate site for mature larvae. Larvae were completed their development inside the fruit and the strips of corrugated carboard were examined daily. When larvae were found in cardboard strips, apples were removed after weighing. Pupae were individually placed in a cup after weighted.

\section{Data analysis}

All tests were conducted in a completely randomized design. Obtained data were analyzed by analysis of variance (ANOVA). All statistical analyses were performed with Minitab 18 . Unless indicated otherwise, all quantitative results are reported as the mean \pm SE.

\section{Results and Discussion Laboratory rearing on green immature apple}

Novel information was found on focusing rearing methods of codling moth on green immature apple in this study. The codling moth was continuously reared on green immature apples (Malus domestica cv. 'Gala') for more than 17 generations in the laboratory. Rearing data for different biological stages is shown in Table 1. Green immature apples can be collected during manual apple thinning in early summer and kept in cold storage in plastic box or bag $(0-5$ 으 $)$ for up to one year (Dickson et al., 1952). Many varieties are suitable, e.g. Jonathan, Winesap, Rome Beauty and Golden Delicious (Dickson et al. 1952; Hamilton and Hathaway, 1966).

Rearing codling moth larvae on mature apples is not easy because relatively few newly hatched larvae penetrate and feed in mature apples, and at room temperature the fruits decay rapidly (Howell, 1991). Howell (1972) stated that green immature apples were more appropriate for penetration $(70 \%$ of neonate larvae enter these apples), and remained as a suitable food for larvae for several weeks. This study has been showed that Gala variety small apple is readily available yearround for winter rearing. The rearing method described here has proved satisfactory over a period of years and can provide a strong laboratory colony at all seasons.

Previous studies have indicated that egg sheets were placed on the apple in trays for infestation by Dickson et al (1952) and later used newly hatched larvae by Hamilton(Hathaway,1966). Geier and Briese (1978) also showed that the rate of successful entries on apple by larvae infested with two neonate larvae was higher on green immature apples $(82 \%)$ than on fully-matured Granny Smith apples (66.5\%). Infestation procedure used in this study provides more successful penetration into apple with the use of sterile needles for small openings in which placed the neonate larvae. 
Table 1. Measurements of biological development stages of the codling moth on green immature apple (Mean \pm SE, N=20)

\begin{tabular}{|c|c|c|c|c|}
\hline Biological stage & Length (mm) & Width (mm) & Weight (mg) & Duration (day) \\
\hline Egg & $1.26 \pm 0.02$ & $0.98 \pm 0.01$ & $0.01 \pm 0.00$ & $4.72 \pm 0.10$ \\
\hline Mature larva(ơ & $12.95 \pm 0.37$ & $2.54 \pm 0.06$ & $41.87 \pm 2.62$ & $15.80 \pm 0.40$ \\
\hline Mature larva (\$) & $14.50 \pm 0.43$ & $2.86 \pm 0.06$ & $56.57 \pm 3.77$ & $16.00 \pm 0.32$ \\
\hline Pupa (o') & $9.11 \pm 0.08$ & $2.45 \pm 0.02$ & $30.37 \pm 0.82$ & $8.79 \pm 0.20$ \\
\hline Pupa (\$) & $10.13 \pm 0.06$ & $2.74 \pm 0.04$ & $43.48 \pm 0.94$ & $8.92 \pm 0.14$ \\
\hline Adult (o') & $7.60 \pm 0.12$ & $1.82 \pm 0.04$ & $16.38 \pm 0.65$ & $16.70 \pm 1.90^{*}$ \\
\hline Adult (P) & $8.89 \pm 0.13$ & $2.32 \pm 0.05$ & $27.85 \pm 0.79$ & $12.2 \pm 0.60^{*}$ \\
\hline
\end{tabular}

*The longevity of codling moth adults fed on $10 \%$ sugar solution.

\section{Egg}

The codling moths deposited their eggs individually or in disorderly small masses (3-20) on the oviposition substrate in the rearing cages. Eggs were ovate, shaped like a convex lens having $1.26 \pm$ $0.02 \mathrm{~mm}$ in length, $0.98 \pm 0.01 \mathrm{~mm}$ in diameter, and weighted about $0.01 \pm 0.001 \mathrm{mg}$ (Table 1). Newly laid eggs were milky white and waxy in appearance (Fig. 2a), and as the embryo developed, a reddish ring appeared in the middle of the egg surface (Fig. $2 b)$. The red spot became the head of the larva and just before hatching larvae became visible through the chorion (Fig. 2c). The egg incubation period was $4.72 \pm 0.10 \mathrm{~d}$ (Table 1 ), with $81.54 \%$ egg viability at $25 \pm 1$ 으 in the laboratory. Similar developmental and survival results on immature apple obtained by Howell (1970).
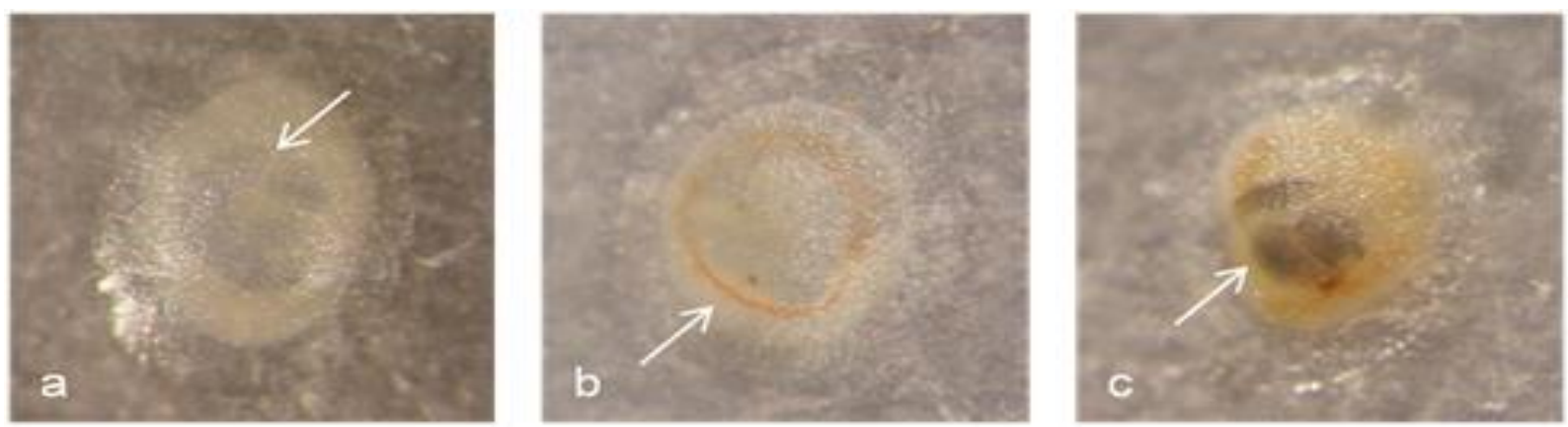

Figure 2. Embryonic development of codling moth, Cydia pomonella. (a) Newly laid egg, (b) Developing egg (reddish ring stage), (c) Egg about to hatch.

\section{Larvae}

The mean widths of the head capsule ranged from $0.31 \pm 0.08 \mathrm{~mm}$ to $1.61 \pm 0.16 \mathrm{~mm}$ for successive five instars on green immature apples in the laboratory (Table 2). The comparison of widths revealed significant differences among instars of codling moth. Williams and McDonald (1982) reported that codling moth had five instar-based head capsule widths on apple, which is similar those of Blomefield and Gliomee (2009).

The first instar was a creamy white or pale yellow, and the body had twelve segments, with long and translucent setae. The head was brown and width of the head was wider than the first larval thoracic segment (Fig. 3a). There was a black shield on the first segment. The legs and prolegs were translucent white or yellow. First instar bored into the fruit peel, creating spiral galleries towards the seed chamber of fruit, and initially fed on the seed then apple tissue. The first instar weighed a mean of $0.14 \pm 0.01 \mathrm{mg}$ and larval duration was $3.70 \pm 0.15$ $d$ in the laboratory (Table 2). The second instar was usually pale white in color, but the head was dark brown and smaller than general body. More apparent on the body were slightly brownish spots and black shields (Fig. 3b). The second instar weighed about $1.54 \pm 0.17 \mathrm{mg}$. The duration of the second instar was $2.40 \pm 0.16 \mathrm{~d}$ in the laboratory. The third instar was similar to second instar, but each larval segment had more brownish spots (Fig. 3c). The third instar weighed about $7.65 \pm 0.58 \mathrm{mg}$. The duration was $2.15 \pm 0.15 \mathrm{~d}$ in the laboratory. The fourth instar was pale white to slightly reddish in color. The head and black shield on the first thoracic segment were near each other (Fig. 3d). The fourth instar weighed about $16.75 \pm 1.18 \mathrm{mg}$ and the duration of fourth instar was $2.20 \pm 0.13 \mathrm{~d}$ in the laboratory (Table 2). The fifth instar was fully grown, and reddish or light brown in appearance with a brown head. The first thoracic shield was not apparent any longer. The body had dark brownish spots (Fig. 3e and f). The fifth instar was used to 
determine the sex of larvae. Male larvae had unique two dark spots near the end of the dorsal side (Fig. 3f). The fifth instar weighed average $49.86 \pm 3.06$ $\mathrm{mg}$. The duration of fifth instar was $4.80 \pm 0.25 \mathrm{~d}$ in the laboratory. The total period of larval development of the codling moth was $15.89 \pm 0.25$ d. The survival of larval stages was $93.3 \%$ on green immature apple in the laboratory $(n=30)$. These results were similar to $\mathrm{Gu}$ et al (2006) as $14.7 \mathrm{~d}$ (mobile strain) and 15.4 (sedentary strain) at 25 으 on semi-artificial diet. There have been different reports on the duration of instars and the total period of larval development. Contrary to our results, Williams and McDonald (1982) found longer duration of interval instar stages (about $4 \mathrm{~d}$ ) at 25드, and completion of larval stage was longer on different mature apple varieties (about 20-21 d). The differences on the duration of each larval stage could depend on larval host, larval density, and intrinsic differences.
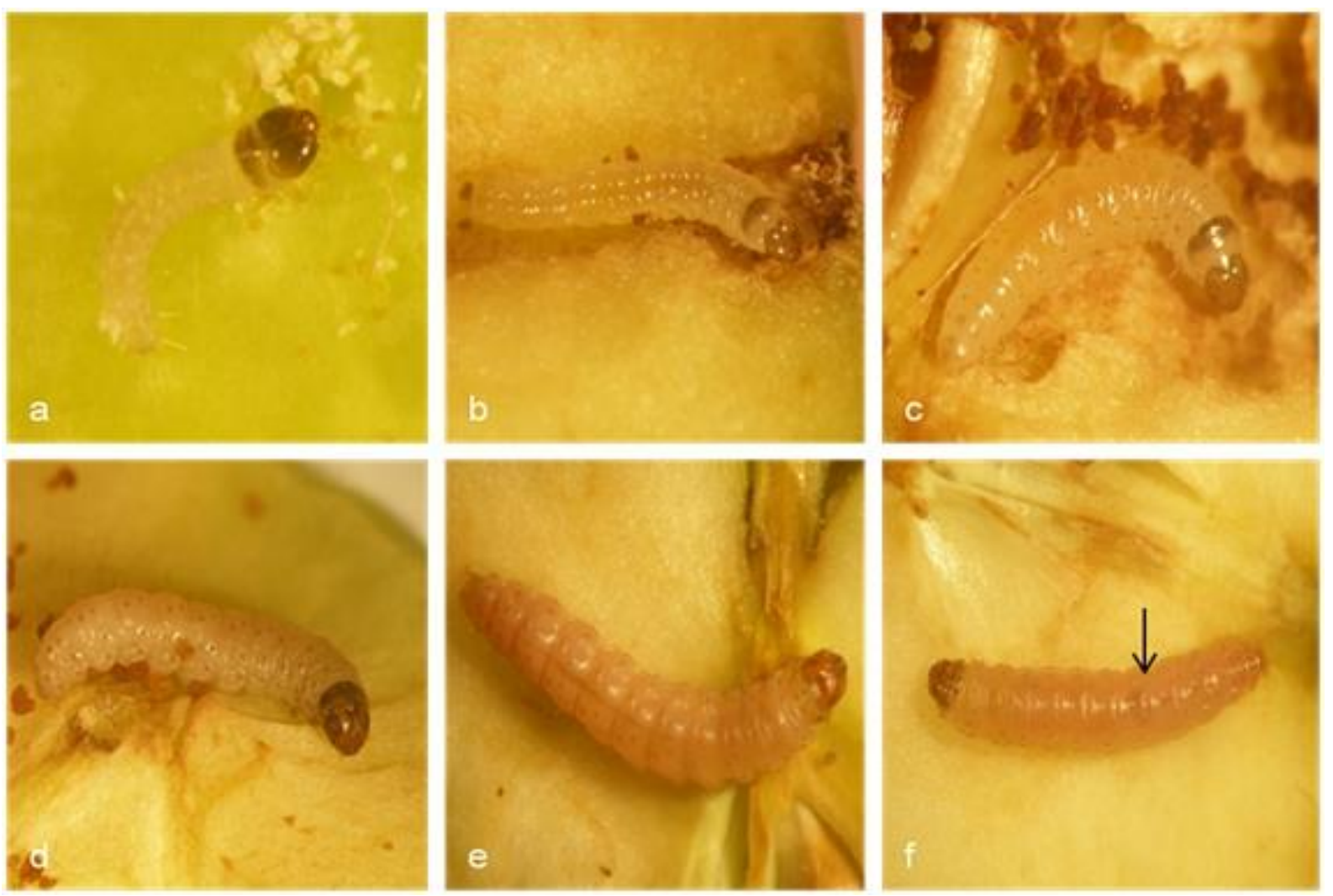

Figure 3. Larval stages of codling moth, Cydia pomonella. (a) I. instar, (b) II. instar, (c) III. instar, (d) IV. instar, (e) V. instar female, (f) V. instar male.

Table 2. Measurements of head capsules widths, weight and duration of larval stages of codling moth on green immature apple moth (Mean $\pm \mathrm{SE}, \mathrm{N}=20$ )*

\begin{tabular}{cccc}
\hline Instar & Head capsule width $(\mathbf{m m})$ & Weight $(\mathbf{m g})$ & Duration (day) \\
\hline I. instar & $0.31 \pm 0.08 \mathrm{a}$ & $0.1 \pm 0.00 \mathrm{a}$ & $3.70 \pm 0.15 \mathrm{~b}$ \\
II. instar & $0.49 \pm 0.13 \mathrm{~b}$ & $1.54 \pm 0.17 \mathrm{~b}$ & $2.40 \pm 0.16 \mathrm{a}$ \\
III. instar & $0.81 \pm 0.06 \mathrm{c}$ & $7.65 \pm 0.58 \mathrm{c}$ & $2.15 \pm 0.15 \mathrm{a}$ \\
IV. instar & $1.18 \pm 0.11 \mathrm{~d}$ & $16.75 \pm 1.18 \mathrm{~d}$ & $2.20 \pm 0.13 \mathrm{a}$ \\
V. instar & $1.61 \pm 0.16 \mathrm{e}$ & $49.83 \pm 3.06 \mathrm{e}$ & $4.80 \pm 0.25 \mathrm{c}$ \\
\hline
\end{tabular}

*The differences among instars marked by not the same letter $(a, b)$ are significant $(P<0.05$, Tukey's test).

Neonate larvae of codling moth completed their development to mature larvae, but the larval density in apple during the larval stage affected the development period of larvae $(P<0.05)$. Larval development period was shorter on the single larva/apple (16.20 $\pm 0.55 \mathrm{~d})$ and longer on nine larvae/apple ( $20.15 \pm 0.75 \mathrm{~d})$, which was similar to the results obtained for four larvae/apple and six larvae/apple (Table 3). The number of pupae developed on a single larvae/apple was similar among treatments. It is found that green immature apples (approximately 20-25 g) were enough to feed two larvae until the pupal stage. Larval density also affected the weight of codling moth pupae $(P<$ $0.05)$. The number of infested larvae and their pupal weight were correlated. The pupal weight of single 
larvae/apple and three larvae/apple were $37.64 \pm$ $1.41 \mathrm{mg}$ and $36.14 \pm 2.24 \mathrm{mg}$, which were heavier than four larvae, six larvae and nine larvae/apple (Table 3). Larval density affected the survival rate of larval development $(P<0.05)$, which was decreased as larval density increased (Fig. 4). The percentages of larval survival were $92.6 \pm 3.7,45.7$ $\pm 1.2,35.2 \pm 0.9$ and $24.1 \pm 1.1$ on larval density one larvae/apple, three larvae/apple, four larvae/apple, six/larvae apple and nine larvae/apple, respectively (Fig. 4). Infested apple with a single larva had a positive effect on their development of larval stages, the survival rate of larva, and weight of pupa for the laboratory rearing. Similar results obtained by Ferro and Harwood (1973), reported that rate of development decreased at higher competitive levels and a small apple was enough to feed approximately three larvae per apple.

Table 3. Larval competition on manually infested green immature apples in the laboratory

\begin{tabular}{lccccc}
\hline Larval density & $\begin{array}{c}\text { Larval duration } \\
\text { (day) }\end{array}$ & No of pupae & $\begin{array}{c}\text { Pupal weight } \\
\text { (mg) }\end{array}$ & $\begin{array}{c}\text { Fruit weight at } \\
\text { the first day (g) }\end{array}$ & $\begin{array}{c}\text { Fruit weight at } \\
\text { the last day (g) }\end{array}$ \\
\hline $\begin{array}{l}\text { One } \\
\text { larvae/apple }\end{array}$ & $16.20 \pm 0.55 \mathrm{a}$ & $8.33 \pm 0.33$ & $37.64 \pm 1.41 \mathrm{a}$ & $19.77 \pm 0.40$ & $15.22 \pm 0.51$ \\
$\begin{array}{l}\text { Three } \\
\text { larvae/apple }\end{array}$ & $16.66 \pm 0.28 \mathrm{a}$ & $12.33 \pm 0.33$ & $36.14 \pm 2.24 \mathrm{a}$ & $24.10 \pm 0.85$ & $17.30 \pm 0.85$ \\
$\begin{array}{l}\text { Four } \\
\text { larvae/apple }\end{array}$ & $19.98 \pm 0.84 \mathrm{~b}$ & $12.66 \pm 0.33$ & $27.92 \pm 2.39 \mathrm{~b}$ & $21.47 \pm 0.93$ & $15.04 \pm 0.81$ \\
$\begin{array}{l}\text { Six } \\
\text { larvae/apple }\end{array}$ & $19.43 \pm 0.54 \mathrm{~b}$ & $13.00 \pm 0.58$ & $30.32 \pm 1.24 \mathrm{ab}$ & $21.83 \pm 0.50$ & $14.48 \pm 0.82$ \\
$\begin{array}{l}\text { Nine } \\
\text { larvae/apple }\end{array}$ & $20.15 \pm 0.75 \mathrm{~b}$ & $13.66 \pm 0.33$ & $31.84 \pm 1.31 \mathrm{ab}$ & $23.90 \pm 0.74$ & $14.75 \pm 0.37$ \\
\hline
\end{tabular}

*The differences between the averages of treatments marked by not the same letter $(a, b)$ are significant $(P<$ 0.05 , Tukey's test).

In nature, the codling moth either lays their eggs individually on the apple or the foliage near the apple (Hughes et al., 2003). Hatched larvae penetrate the apple fruit through calyx or stalk ends while the fruit is small (Blomefield, 1989). However, in the laboratory, when small apples are placed in the adult cage, codling moth adults deposit eggs directly as clusters. Most of hatched larvae burrow successfully into the apples. In addition, small apples decay rapidly if multiply infestation, because of larval competition and larvae either killed each other or their growth was suppressed until more dominant larva was pupated (Howell, 1970). Therefore, this study suggests infestation with a single larva per apple for laboratory rearing.

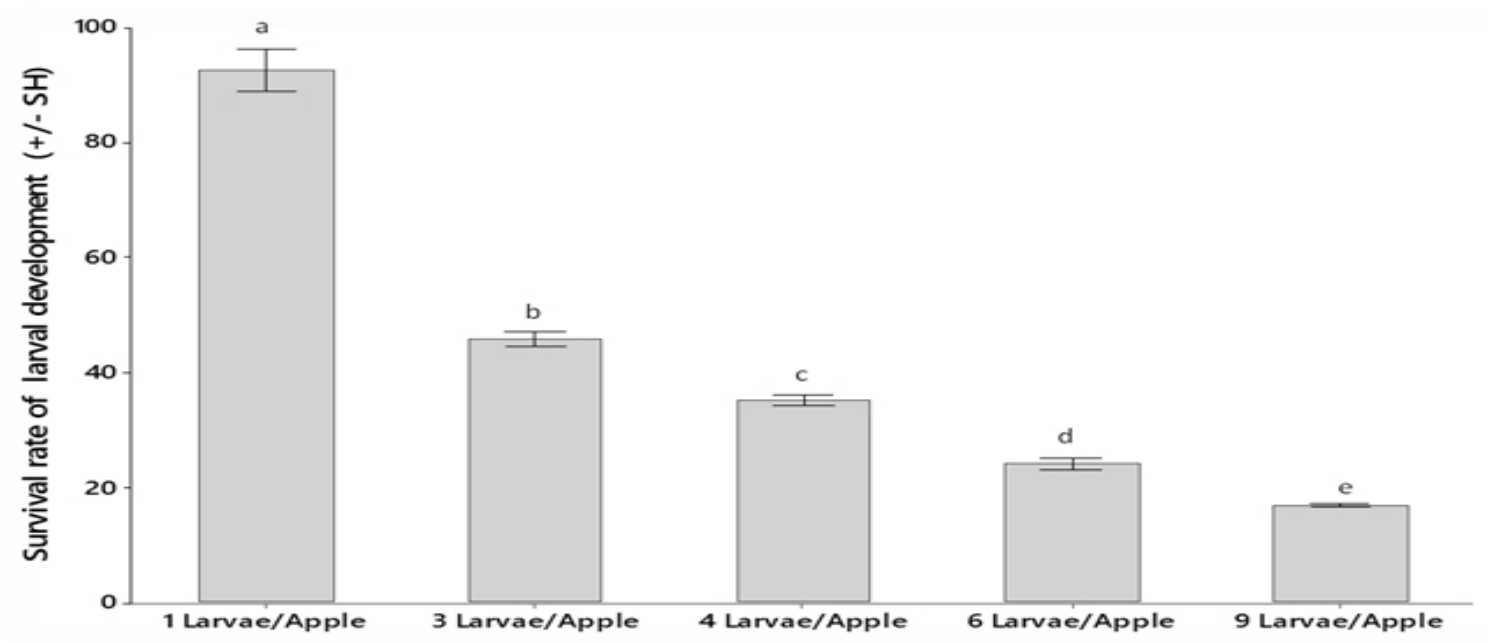

Figure 4. Survival of larval development of the codling moth on manually infested green immature apples. Means within different letter significantly different than each other ( $p \leq 0.5$, Tukey's test).

\section{Pupae}

Mature larvae stopped feeding inside the apple, left the fruit (Fig. 5a), and spun a cocoon in corrugated cardboard strips. They stayed there about $1.85 \pm 0.22 \mathrm{~d}$ as prepupae. They had a characteristic pupal appearance (Fig. 5b). Initially, 
the pupae were soft, and yellowish to light brown in color. Pupal color turned to brown on the following day. Developing wings were apparent on the dorsal side of pupa. Female pupa was $10.13 \pm 0.06 \mathrm{~mm}$ in length, $2.74 \pm 0.04 \mathrm{~mm}$ in width, and weighed about $43.48 \pm 0.94 \mathrm{mg}$ (Table 1). Male pupa was $9.11 \pm$ $0.08 \mathrm{~mm}$ in length, $2.45 \pm 0.02 \mathrm{~mm}$ in diameter, and weighed about $30.37 \pm 0.82 \mathrm{mg}$ (Table 1). The duration of pupal stage was about $8.90 \pm 0.10 \mathrm{~d}$ at $25 \pm 1$ 으 $\mathrm{C}$ in the laboratory. Pupal survival was $87.5 \%$. The observed sex ratio was (male:female) 1:1.2 in the laboratory.
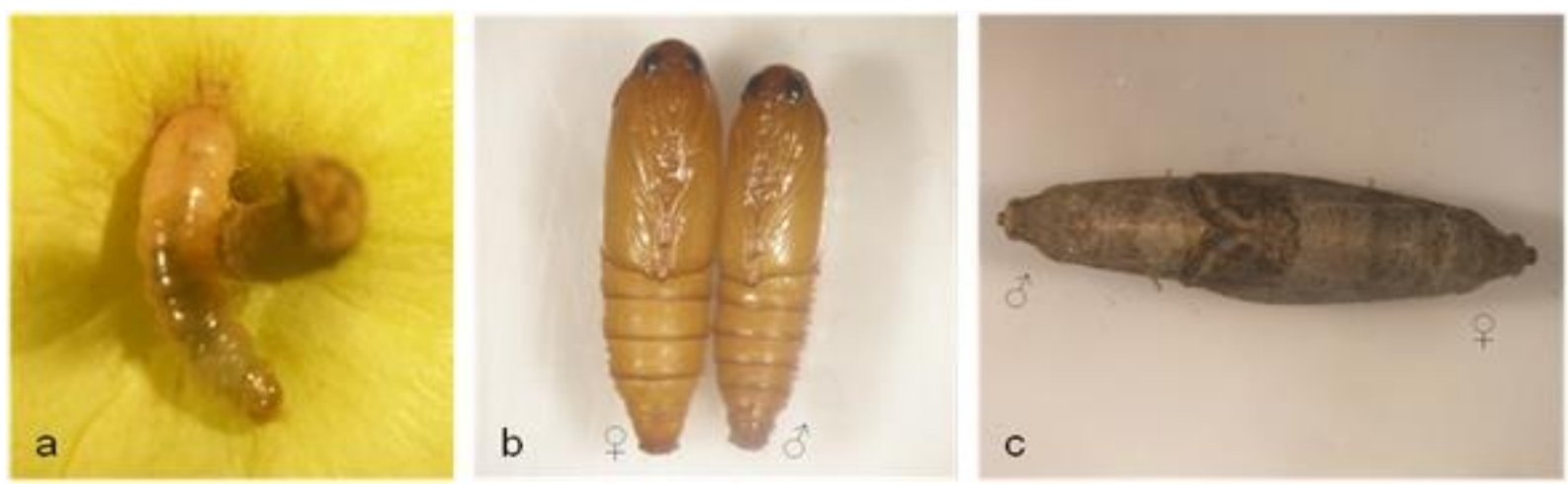

Figure 5. The reared codling moth, Cydia pomonella in the laboratory. (a) Mature larva left the apple, (b) Ventral view of codling moth male and female pupae, (c) Mating of male and female moths.

\section{Adults}

Adults were similar in appearance. They were pale gray, wings were wavy gray-white pattern, and triangular at rest. There were characteristic brown lines on lower part of forewings which were surrounded by two shiny golden spots or tending towards bronze (Fig. 5c). The wingspan was $17.05 \pm 0.50 \mathrm{~mm}$ in males and $19.80 \pm 0.50 \mathrm{~mm}$ in females (Table 1). Males were measured $7.60 \pm 0.12 \mathrm{~mm}$ in length, $1.82 \pm 0.04 \mathrm{~mm}$ in diameter, and weighed about $17.38 \pm 0.65 \mathrm{mg}$ (Table 1). Females were $8.89 \pm 0.13 \mathrm{~mm}$ in length, $2.32 \pm 0.05 \mathrm{~mm}$ in diameter, and weighed about $27.85 \pm 0.79 \mathrm{mg}$ in the laboratory (Table 1). Previous studies reported that the adult weights similar to present results (Hathaway et al., 1971; Geier and Briese, 1978).

Adult food affected the duration of preoviposition period, fecundity and egg viability of the codling moth in the laboratory $(P<0.05)$ (Table 4). However, the duration of postoviposition period was similar between treatments. The preoviposition period lasted about $2.90 \pm 0.20 \mathrm{~d}$ for adults fed on $10 \%$ sugar solution, and longer than those fed distilled water. Female oviposition periods were $7.40 \pm 0.80 \mathrm{~d}$ on $10 \%$ sugar solution and $6.00 \pm 0.80 \mathrm{~d}$ on distilled water. The duration of postoviposition periods was $1.90 \pm 0.30 \mathrm{~d}$ and 1.70 $\pm 0.20 \mathrm{~d}$ on $10 \%$ sugar solution and on distilled water, respectively (Table 4). The peaks of
Previous studies have shown that mature larvae left the apple to pupate, usually in corrugated cardboard strips (Dickson et al., 1952; Geier and Briese, 1978; Williams and McDonald, 1982; Gu et al., 2006). Hathaway et al (1971) found pupal weights was $34.5 \mathrm{mg}$ in male and $43.4 \mathrm{mg}$ in female with $87 \%$ adult emergence, while Howell (1970) determined $34.1-35.9 \mathrm{mg}$ and $42.2 \mathrm{mg}$ on green immature apple, respectively. Pupae reared on green immature apples in their study were similar in weight to present results. 
Table 4. The fitness parameters of codling moth female on green immature apple*

\begin{tabular}{lcc}
\hline Female fitness parameter & 10\% sugar solution & Distilled water \\
\hline Preoviposition (d) & $2.90 \pm 0.20 \mathrm{a}$ & $5.50 \pm 0.50 \mathrm{~b}$ \\
Ovipozition (d) & $7.40 \pm 0.80 \mathrm{a}$ & $6.00 \pm 0.80 \mathrm{a}$ \\
Postoviposition (d) & $1.90 \pm 0.30 \mathrm{a}$ & $1.70 \pm 0.20 \mathrm{a}$ \\
No. of eggs laid per female & $160.60 \pm 7.80 \mathrm{a}$ & $106.40 \pm 13.00 \mathrm{~b}$ \\
Egg viability (\%) & $83.90 \mathrm{a}$ & $71.70 \mathrm{~b}$ \\
\hline
\end{tabular}

*The differences between the averages of treatments marked by not the same letter $(a, b)$ are significant $(P<$ 0.05 , Tukey's test).

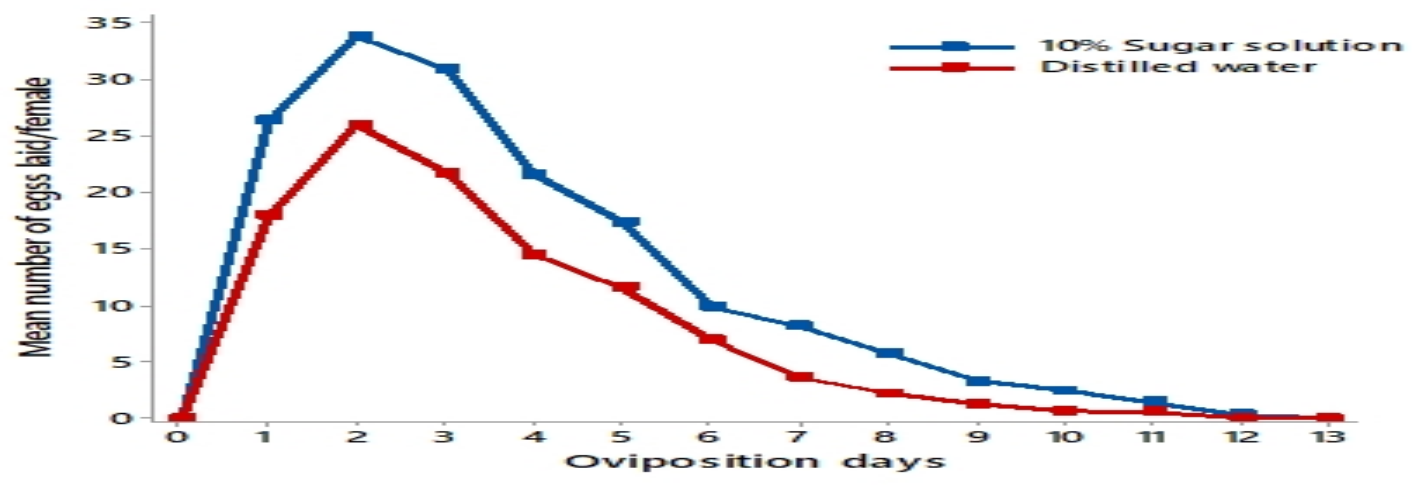

Figure 6. Average number of daily eggs laid by codling moth females on two feeding source.

Adult longevity differed between females and males. Adult feeding source did not affect adult longevity of females and males $(P>0.05)$. However, males had longer lifespan than females. The mean longevity of females and males fed on $10 \%$ sugar solution was $12.20 \pm 0.60 \mathrm{~d}$ and $16.70 \pm 1.90 \mathrm{~d}$, respectively. The mean longevity of females and males fed on distilled water was $13.00 \pm 0.90 \mathrm{~d}$ and $17.30 \pm 1.60 \mathrm{~d}$ in the mating cage. The duration from egg to adult stages was $29.50 \pm 0.30$ in the laboratory. The treatment of $10 \%$ sugar solution for adult food had a positive effect on fecundity and egg viability. Similar results also have been found in several studies related to codling moth (Howell, 1970; Vickers, 1997; Gu et al., 2006; Blomefield and Gliomee, 2011).

\section{Conclusion}

In present study, novel information was found on focusing laboratory rearing methods of codling moth on green immature apples. The codling moth was continuously reared on green immature apples (Malus domestica cv. 'Gala') for more than 17 generations with no evidence of disease in the colony. It was determined that the effects of larval competition in an apple during the larval development suggested singly infestation with codling moth larvae for laboratory rearing. Otherwise, some biological parameters may be affected negatively. Moths mated readily and laid eggs on transparent paper placed in the cages. Adult food had a positive effect on the number of eggs laid per female and egg viability. This study may help to researchers to adapt field population of C. pomonella for rearing on green immature apple in the laboratory. Laboratory rearing on green immature apples may be assisted further researches, including mating, behavioral, biological and physiological, and evaluating its success to maintain large-scale rearing.

\section{Acknowledgement}

The authors thank to Professor Emeritus James L. Nation (University of Florida, Department of Entomology and Nematology, Gainesville, USA) for his valuable comments.

¥: This research study is a part of the master thesis of the first author's. The study was financially supported by Çanakkale Onsekiz Mart University Scientific Research Council (BAP, Project No: FYL2018-2619).

\section{References}

Awmack, C.S., Leather, S.R. 2002. Host plant quality and fecundity in herbivorous insects. Annual Review of Entomology, 47(1): 817-844.

Barnes, M.M. 1991. Codling moth occurrence, host race formation, and damage. In: van der Geest L.P.S., Evenhuis H.H (Eds.). Tortricid Pests: Their Biology, Natural Enemies and Control. Elsevier, Amsterdam, Netherlands, pp. 313-328.

Beers, E.H., Suckling, D.M., Prokopy, R.J., Avilla, J. 2003. Ecology and Management of Apple 
Arthropod Pests. In: Feree D.C., Warrington I. (Eds.). Apples: botany, production and uses. CABI Publishing, Wallingford, United Kingdom, pp. 489-519.

Blomefield, T.L. 1989. Economic importance of false codling moth, Cryptophlebia leucotreta, and codling moth, Cydia pomonella, on peaches, nectarines and plums. Phytophylactica, 21(4): 435-436.

Blomefield, T.L., Giliomee, J.H. 2009. Head capsule widths and the rate of development of the instars of codling moth, Cydia pomonella (Linnaeus) (Lepidoptera: Tortricidae). African Entomology, 17(1): 28-33.

Blomefield, T.L., Giliomee, J.H. 2011. Effect of temperature on the oviposition, longevity and mating of codling moth, Cydia pomonella (L.) (Lepidoptera: Tortricidae). African Entomology, 19(1): 42-60.

Blomefield, T.L., Giliomee, J.H. 2012. Fecundity and mortality of codling moth, Cydia pomonella (L.) (Lepidoptera: Tortricidae), under field conditions in South Africa. African Entomology, 20(2): 316-324.

Blommers, L.H., 1994. Integrated pest management in European apple orchards. Annual Review of Entomology, 39(1): 213-241.

Boivin, T., Bouvier, J.C., Beslay, D., Sauphanor, B. 2004. Variability in diapause propensity within populations of a temperate insect species: interactions between insecticide resistance genes and photoperiodism. Biological Journal of the Linnean Society, 83(3): 341-351.

Bosch, D., Rodríguez, M.A., Avilla, J. 2018. Monitoring resistance of Cydia pomonella (L.) Spanish field populations to new chemical insecticides and the mechanisms involved. Pest Management Science, 74(4): 933-943.

Brinton, F.E., Proverbs, M.D., Carty, B.E. 1969. Artificial diet for mass production of the codling moth, Carpocapsa pomonella (Lepidoptera: Olethreutidae). The Canadian Entomologist, 101(6): 577-584.

Dickson, R.C., Barnes, M.M., Turzan C.L. 1952. Continuous rearing of the codling moth. Journal of Economic Entomology, 45(1): 6668.

FAOSTAT, 2017. Food and Agricultural Organization of United Nations. http://www.fao.org/faostat/en/\#data/QC (Accessed date: 20 March 2019).

Ferro, D.N., Harwood, R.F. 1973. Intraspecific larval competition by the codling Moth, Laspeyresia ponwllella. Environmental Entomology, 2(5): 783-790.
Geier, P.W., Briese, D.T. 1978. The demographic performance of a laboratory strain of codling moth, Cydia pomonella (Lepidoptera: Tortricidae). Journal of Applied Ecology, 679696.

Genç, H. 2016. The tomato leafminer, Tuta absoluta (Meyrick) (Lepidoptera: Gelechiidae): pupal key characters for sexing individuals. Turkish Journal of Zoology, 40(5): 801-805.

Gu, H., Hughes, J., Dorn, S. 2006. Trade-off between mobility and fitness in Cydia pomonella L. (Lepidoptera: Tortricidae). Ecological Entomology, 31(1): 68-74.

Hamilton, D.W., Hathaway, D.O. 1966. Codling Moths. In: Smith C.N. (ed.). Insect Colonization and Mass Production, Academic Press Academic Press, New York, USA, pp. 339-354.

Hancock, F.J., Luby, J.J., Brown, S.K., Lobos, G.A. 2008. Apples. In: Hancock J.F. (Ed.). Temperate Fruit Crop Breeding: Germplasm to Genomics. Springer Science \& Business Media, Michigan, USA, pp. 1-37.

Hathaway, D.O., Clift, A.E., Butt, B.A. 1971. Development and fecundity of codling moths reared on artificial diets or immature apples. Journal of Economic Entomology, 64(5): 1088-1090.

Hathaway, D.O., Lydin, L.V., Butt, B.A., Morton, L.J. 1973. Monitoring mass rearing of the codling moth. Journal of Economic Entomology, 66(2): 390-393.

Howell, J.F. 1970. Rearing the codling moth on an artificial diet. Journal of Economic Entomology, 63(4): 1148-1150.

Howell, J.F. 1972. Modifications of the artificial diet for codling moths to improve larval acceptance and production of moths. Journal of Economic Entomology, 65(1): 5759.

Howell, J.F. 1991. Reproductive Biology. In: Van Der Geest L.P.S., Evenhuis H.H. (Eds.). Tortricid Pests: Their Biology, Natural Enemies and Control. Elsevier, Amsterdam, Netherlands, pp. 157-174.

Hughes, W.O.H., Gailey, D., Knapp, J.J. 2003. Host location by adult and larval codling moth and the potential for its disruption by the application of kairomones. Entomologia Experimentalis et Applicata, 106: 147-153.

İsci, M., Ay, R. 2017. Determination of resistance and resistance mechanisms to thiacloprid in Cydia pomonella L. (Lepidoptera: Tortricidae) populations collected from apple orchards in Isparta Province, Turkey. Crop Protection, 91: 82-88. 
Jiang, D. Chen, S., Hao, M., Fu, J., Ding, F. 2018. Mapping the potential global codling moth (Cydia pomonella L.) distribution based on a machine learning method. Scientific Reports, 8(1): 13093.

Kovanci, O.B. 2015. Co-application of microencapsulated pear ester and codlemone for mating disruption of Cydia pomonella. Journal of Pest Science, 88 (2): 311-319.

Kuyulu, A., Genç, H. 2018. Çanakkale ili meyve alanlarında elma içkurdu Cydia pomonella (L.) (Lepidoptera: Tortricidae)'nun yayılışı üzerine bir araştırma. ÇOMÜ Ziraat Fakültesi Dergisi, 6: 85-91.

McGhee, P.S., Miller, J.R., Thomson, D.R., Gut, L.J. 2016. Optimizing aerosol dispensers for mating disruption of codling moth, Cydia pomonella L. Journal of Chemical Ecology, 42(7): 612-616.

Men, Q.L., Chen, M.H., Zhang, Y.L., Feng, J.N. 2013. Genetic structure and diversity of a newly invasive species, the codling moth, Cydia pomonella (L.) (Lepidoptera: Tortricidae) in China. Biological invasions, 15(2): 447-458.

Meraner, A., Brandstätter, A., Thaler, R., Aray, B., Unterlechner, M., Niederstätter, $H_{\text {., }}$ Dallinger, R. 2008. Molecular phylogeny and population structure of the codling moth (Cydia pomonella) in Central Europe: I. Ancient clade splitting revealed by mitochondrial haplotype markers. Molecular Phylogenetics and Evolution, 48(3): 825-837.

Nation, J.L. 2015. Insect Physiology and Biochemistry ( $3^{\text {rd }}$ ed.). Florida, USA, $690 \mathrm{pp}$.

Öztemiz, S., Küden, A., Nas, S., Lavkor, I. 2017. Efficacy of Trichogramma evanescens and Bacillus thuringiensis var. kurstaki in control of Cydia pomonella (L.) in Turkey. Turkish Journal of Agriculture and Forestry, 41(3): 201-207.

Pajač, I., Božena, B., Mikac, M.K., Pejić, I. 2012. New insights into the biology and ecology of Cydia pomonella from appleorchards in Croatia. Bulletin of Insectology, 65(2): 185-193.

Sigsgaard, L. Herz A., Korsgaard M., Wührer B. 2017. Mass release of Trichogramma evanescens and $T$. cacoeciae can reduce damage by the apple codling moth Cydia pomonella in organic orchards under pheromone disruption. Insects, 8(2): 41.

Thaler, R., Brandstätter, A., Meraner, A., Chabicovski, M., Parson, W., Zelger, R., Dallinger, R. 2008. Molecular phylogeny and population structure of the codling moth (Cydia pomonella) in Central Europe: II. AFLP analysis reflects human-aided local adaptation of a global pest species. Molecular Phylogenetics and Evolution, 48 (3): 838-849.

Vetter, R.S., Robert, M.E., Baker, C.T. 1989. Mass rearing of the oriental fruit moth (Lepidoptera: Tortricidae). Journal of Economic Entomology, 82(6): 1825-1829.

Vickers, R.A. 1997. Effect of delayed mating on oviposition pattern, fecundity and fertility in codling moth, Cydia pomonella (L.) (Lepidoptera: Tortricidae). Australian Journal of Entomology, 36(2): 179-182.

Williams, D.G., McDonald, G. 1982. The duration and number of the immature stages of codling moth Cydia pomonella (L.) (Tortricidae: Lepidoptera). Australian Journal of Entomology, 21(1): 1-4. 